ACTA MYCOLOGICA

Vol. 42 (2): 281-286

2007
Dedicated to Professor Alina Skirgietto

on the occasion of her ninety-fifth birthday

\title{
Usnea florida - threatened species of rich biotopes in the Polish Eastern Carpathians
}

\author{
ROBERT KOŚCIELNIAK \\ Institute of Biology, Pedagogical Academy in Krakow, Podbrzezie 3 \\ PL-31-054 Kraków, rkosciel@ap.krakow.pl
}

Kościelniak R.: Usnea florida - threatened species of rich biotopes in the Polish Eastern Carpathians. Acta Mycol. 42 (2): 281-286, 2007.

The paper presents the results of the research on Usnea florida (L.) Webber ex F.H. Wigg. in the Polish Eastern Carpathians. Three new sites of this species have been found in the Bieszczady National Park at an altitude of $800-880$ m. U. florida grows on the bark of Fagus sylvatica, Populus tremula and Betula sp. The historical sites of this species in the Western Bieszczady Mts have not been confirmed. In Poland $U$. florida has also been recorded in the Białowieża Forest and Gdańskie Pomerania.

Key words: threatened, epiphytic lichens, Western Bieszczady Mts, Bieszczady National Park, SE Poland

\section{INTRODUCTION}

Apart from the Białowieża Forest, the Western Bieszczady Mts, especially the Bieszczady National Park, are an important centre of lichen biodiversity in Poland (Czyżewska 2003; Kościelniak 2006, in print). From the Polish Eastern Carpathians over 610 lichen species have been reported and about 540 of them have been recorded in the recent years (Kościelniak, Kiszka 2003). Almost 70 species are considered to be extinct in this part of the Polish Carpathians and most of them belong to the Bryoria, Nephroma, Peltigera and Usnea genera. The intensive lichenological research in the area of the Bieszczady National Park carried out since 1999 has shown that a lot of sensitive species are still present there, e.g. Melaspilea granitophila (Th.Fr.) Coppins, so far believed to be extinct in Poland (Koście ln iak, Kiszk a 2006), as well as other valuable species such as Alectoria ochroleuca (Hoffm.) A.Massal, Bryoria bicolor (Ehrh.) Brodo \& D.Hawksw., Evernia divaricata (L.) Ach., Fuscopannaria praetermissa (Nyl.) P.M.Jørg., Hypogymnia vittata (Ach.) Parrique, Icmadophila ericetorum (L.) Zahlbr, Parmotrema chinense (Osbeck) Hale \& Ahti and Usnea florida (L.) Weber ex F.H. Wigg. (unpbl. data). 
The paper presents the results of the research on Usnea florida, an epiphytic component of the Bieszczady National Park biota. The taxon was recently subjected to molecular studies, which showed that together with Usnea subfloridana Stirt. it forms one polymorphic species and its differentiating features include the presence of apothecia and lack of vegetative propagula (Articus et al. 2002.). However, in many later publications and checklists it is treated traditionally (e.g. Cieśliński et al. 2003; Fałtynowicz 2003; Kondratyuk et al. 2003; Bielczyk et al. 2004; Santess on et al. 2004; Index Fungorum 2007 ) and it is considered in this way also in this paper.

\section{MATERIAL AND METHODS}

The research on the lichen biota of the Bieszczady National Park has been carried out since 1999. A regular net of squares was used as the method of choice (Faliński 1990). The grid squares, 1 x $1 \mathrm{~km}$, were adjusted to the Polish ATPOL grid squares system, modified to accommodate lichens [Gf 69, 70 and Gg 70] (see Cieśliński, Fałtynowicz 1993). In each square the biggest possible number of habitats and substrata were studied and the abundance and vitality of the lichen thalli were determined. In the case of $U$. florida, small fragments of the thallus were taken in order to analyse them in the laboratory. The herbarial material was deposited in the Herbarium KRAP-L (Kraków). The sites were localised with a GPS and the absolute altitude was established using an altimeter $( \pm 10 \mathrm{~m})$. The map of distribution was based on the river network

\section{RESULTS AND DISSCUSSION}

Usnea florida is a new component of the epiphytic biota of forest lichens in the Bieszczady National Park and it was recorded on the following sites (Fig. 1):

Site I. Poland: Western Bieszczady Mts, Bieszczady National Park, [Gf 6985] border zone between Chrusty and Selenowa, 4905' 00'N/2237'39'E, slope NNE, alt. ca 880 m, 18 June 2006. On bark of Fagus sylvatica in beech forest Dentario glandulosae-Fagetum typicum. The species was found in the tree-crown of a blowndown beech, about 15 meters from the base of the trunk. The population numbers 3 thalli, one of them is formed typically of the species, with numerous apothecia (Fig. 2), others possess single young apothecia. $U$. florida was associated with Buellia griseowirens (Turner \& Borrer ex Sm.) Almb., Graphis scripta (L.) Ach., Hypogymnia physodes (L.) Nyl., Lecanora argentata (Ach.) Malme, L. carpinea (L.) Vain., L. leptyrodes (Nyl.) Degel., L. pulicaris (Pers.) Ach, Lobaria pulmonaria (L.) Hoffm, Melanelia subaurifera (Nyl.) Essl., Menegazzia terebrata (Hoffm.) Körb, Parmelia saxatilis (L.) Ach. (c. apoth.), P. sulcata Taylor, Pertusaria amara (Ach.) Nyl, Phlyctis argena (Spreng.) Flot., Platismatia glauca (L.) W.L.Culb. \& C.F.Culb, Pseudevernia furfuracea (L.) Zopf, Pyrenula nitida (Weigel) Ach., Scoliciosporum chlorococcum (Graeve ex Stenh.) Vězda as well as some species from the Lepraria genus, nonidentified so far.

Site II. [Gf 7000] - Wołosate, SW slope of Szeroki Wierch, the Zwór Stream valley, 49-04'05'N/22041'26”E, alt. ca 800 m, 2 September 2005, leg. J. Kiszka 


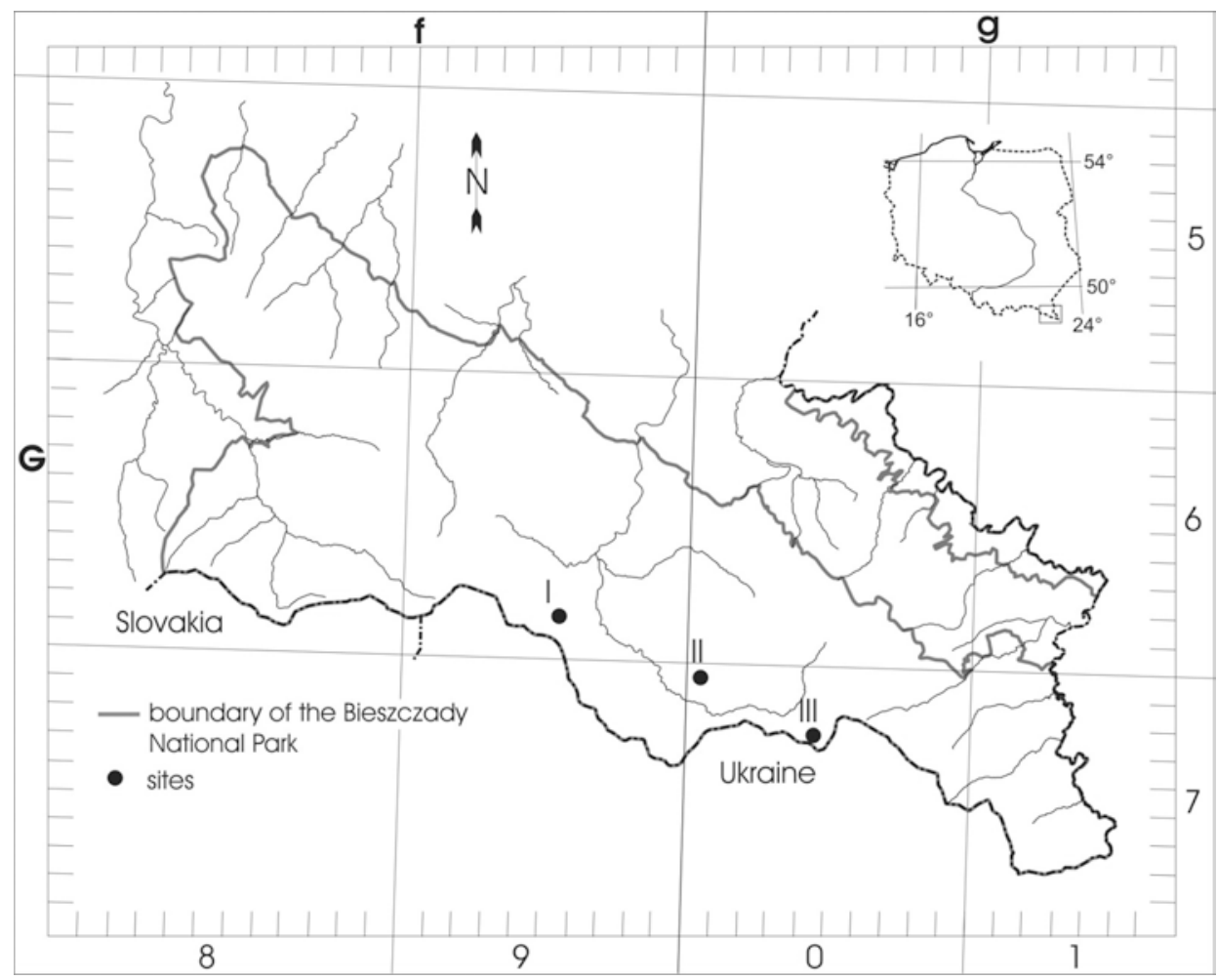

Fig. 1. Distribution of the sites of Usnea florida in the Bieszczady National Park on a background of ATPOL net.

(KRAP-L). On the bark of Populus tremula near the stream. A young specimen with single apothecia. Accompanying species: Amandinea punctata (Hoffm.) Coppins \& Schleid, Hypogymnia physodes, Lecanora carpinea, L. chlarothera Nyl., L. pulicaris, Lecidella elaeochroma (Ach.) M.Choisy, Parmelia saxatilis, Parmelia sulcata and Phlyctis argena.

Site III. [Gg 7024] - border zone between the Bukowska Pass and the Beskid Pass, 4902'46'N/2244'49'E, alt. ca 870 m, 7 June 2005. On the bark of Betula sp. at the edge of an overgrowing forest clearing in Dentario glandulosae-Fagetum typicum. A single specimen with several apothecia. Accompanying species: Amandinea punctata, Evernia prunastri (L.) Ach , Hypogymnia physodes, H. tubulosa (Schaer.) Hav., Lecanora argentata, L. carpinea, L. pulicaris, Ochrolechia arborea (Kreyer) Almb., Parmelia saxatilis, Parmeliopsis ambigua (Wulfen) Nyl., Phlyctis argena, Placynthiella icmalea (Ach.) Coppins \& P.James, Platismatia glauca, Pseudevernia furfuracea, Ramalina farinacea (L.) Ach, R. pollinaria (Westr.) Ach, Usnea subfloridana and Vulpicida pinastri (Scop.) J.-E.Mattsson \& M.J.Lai.

So far Usnea florida has been reported from the Polish Eastern Carpathians from a site near Lesko (Rydzak 1955) and from the hill of Falowa near Kalnica (Gla nc, Tobolewski 1960). Both sites are situated outside the Bieszczady National Park. On neither of them, or even in their vicinity, the occurrence of this species has been 
confirmed in the recent studies. For a long time during the intensive lichenolgical research carried out since the late 1980s $U$. florida was considered to be extinct in the Polish Eastern Carpathians (as in the Western Carpathians). The circumstances in which the species was found suggest that the number of its sites in the Bieszczady might be bigger, especially because it frequently occurs in the Ukrainian part of the Eastern Carpathians (Bielczyk, pers. comm.). The specimens collected on Sites II and III were juvenile and possessed apothecia without vegetative propagula. As far as their habitat is concerned, they resembled Usnea subfloriana, which is quite a frequent species in the Bieszczady Mts. and on some sites it occurs in large numbers. On Site I, where the typical form with numerous, well-developed apothecia was recorded, the specimen was found high in the crown of a blown-down tree. During the field research Usnea ssp. thalli were often observed in large numbers in the upper parts of tree-trunks and crowns, whereas in the lower, accessible to researchers parts of trunks only common and often scarce species were recorded. In April 2007 some blown-down old fir-trees were found. The upper parts of their trunks and branches were covered with huge numbers of Usnea thalli (e.g. Usnea subfloridana, $U$. filipendula Stirt. and U. hirta (L.) Weber ex F.H. Wigg.) together with numerous representatives of the Bryoria genus (Fig. 3). On upper branches of several firs Usnea with apothecia was also noted (cf. Usnea faginea Motyka). In the collected material $U$. florida seems very likely to occur.

Species belonging to the Usnea genus, as well as numerous species from the Bryoria genus, obviously prefer upper parts of trunks and tree-crowns. The thesis can be supported by observations of windfalls carried out in the Tatra Mts. - both nowadays (in the vicinity of Tatranská Lomnica in Slovakia - Bielczyk, pers. comm.), and in the 1960s (Kiszka unpbl. data). In the paper by Rydzak (1955) on both mentioned sites Usnea florida was recorded in upper parts of tree-crowns in company with $U$. filipendula, U. subfloridana and Bryoria jubata auct. Also Glanc and Tobolewski (1960) provided information on rare species found exclusively, or almost exclusively, in tree-crowns, e.g. U. faginea, U. lapponica Vain. or Bryoria smithii (Du Rietz) Brodo \& D.Hawksw. The above presented facts prove that it is the natural habitat for this group of lichens. As compared with lower parts of trunks, lichens growing there have better access to light and higher relative air humidity thanks to transpiration from tree-leaves.

At present Usnea florida belongs to the CR (Critically Endangered) category in Poland (Cieśliński et al. 2003), and locally it is considered to be Regionally Extinct (RE category; see Cieślinski, Łubek 2003; Kossowska 2003; Lipnicki 2003). In the past this species was dispersed, yet not very frequent in different regions of Poland, e.g. in the Pomerania, in forests of North-Eastern Poland, on Małopolska and Krakowsko-Częstochowska Uplands, in Upper Silesia, the Góry Świętokrzyskie Mts, the Sudetes, the Western and Eastern Carpathians. However, most of the records come from before 1900 or the first half of the $20^{\text {th }}$ century (see Fałtynowicz 2003). Nowadays only several sites of this species are known from Poland: in the Białowieża Forest (Cieśliński 2003), in the Eastern Pomerania (Kukwa 2005) and those presented in this paper. 


\section{CONCLUSIONS}

Due to its natural habitat, Usnea florida is a species whose occurrence in Poland does not seem to be completely established. It appears that cooperation with qualified foresters who can control and monitor tree-crowns during the process of cutting down trees might be very useful in this respect. It is particularly important in national parks where the occurrence of this species is the most probable. Such cooperation takes place in the Bieszczady National Park and has proved to be fruitful.

Even if Usnea florida is treated as one species with U. subfloridana, the fertile forms of this species are still exceptional rarities not only in Poland. Therefore, their occurrence in the Bieszczady National Park emphasises the uniqueness of the area and its significance as an important refuge for lichens in the Eastern Carpathians and in Poland.

Acknowledgements: My thanks are due to Professor Krystyna Czyżewska (University of Łódź) for devoting time to fruitful discussions and for her critical comments. I am also grateful to Tadeusz Kwolek (Bieszczady National Park) for his assistance while collecting material for the research.

\section{REFERENCES}

Articus K., Mattsson J.-E., Tibell L., Grube M., Wedin M. 2002. Ribosomal DNA and B-tubulin data do not support the separation of the lichens Usnea florida and U. subfloridana as distinct species. Mycological Research 4: 412-418.

Bielczyk U., Lackovičová A., Farkas E., Lökös L., Liška J., Breuss O., Kondratyuk S. Ya. 2004. Checklist of lichens of the Western Carpathians. W. Szafer Institute of Botany, Polish Academy of Sciences, Kraków, 181 pp.

Cieśliński S. 2003. Atlas rozmieszczenia porostów (Lichenes) w Polsce Północno-Wschodniej (Distribution Atlas of lichens (Lichenes) in North-Eastern Poland). Phytocoenosis 15 (N.S.), Suppl. Cartogr. Geobot. 15, 430 pp.

Cieśliński S., Fałtynowicz W. (eds.) 1993. Atlas of the geographical distribution of lichens in Poland. 1. W. Szafer Institute of Botany, Polish Academy of Sciences, Kraków.

Cieśliński S., Łubek A. 2003. Czerwona lista porostów zagrożonych w Górach Świętokrzyskich (Red List of threatened lichens in the Świętokrzyskie Mts.). Monogr. Bot. 91: 143-158.

Cieśliński S., Czyżewska K., Fabiszewski J. 2003. Czerwona lista porostów wymarłych i zagrożonych w Polsce (Red list of extinct and threatened lichens in Poland). Monogr. Bot. 91: $13-62$.

Czyżewska K. 2003. Ocena zagrożenia bioty porostów Polski (Evaluations of the threat to lichens in Poland). Monogr. Bot. 91: 241-249.

Faliński J.B. 1990. Kartografia geobotaniczna. Część I. PPWK, Warszawa-Wrocław.

Fałtynowicz W. 2003. The lichens, lichenicolous and allied fungi of Poland. An annotated checklist. W. Szafer Institute of Botany, Polish Academy of Sciences, Kraków, 435 pp.

Glanc K., Tobolewski Z. 1960. Porosty Bieszczadów Zachodnich (Lichenes of the Western Bieszczady). Pozn. Tow. Przyj. Nauk, Wydz. Mat.-Przyr. Prace Kom. Biol. 21 (4):1-108.

Index Fungorum. 2007. www.indexfungorum.org/Names.asp

Kondratyuk S. Ya., Popova L.P., Lackovičová A., Pišút J. 2003. A catalogue of Eastern Carpathians Lichens. M.H. Kholodny Institute of Botany. Kiev-Bratislava, 264 pp.

Kossowska M. 2003. Czerwona lista porostów zagrożonych w polskiej części Sudetów (Red List of threatened lichens in Polish part of the Sudety Mts.). Monogr. Bot. 91: 201-221.

Kościelniak R. 2006 (In print). The Bieszczady Mts as a refuge for protected and threatened lichens in Poland. Polish Bot. Stud.

Kościelniak R., Kiszka J. 2003. The lichens and allied fungi of the Polish Eastern Carpathians. (In:) U. Bielczyk (ed.). The lichens and allied fungi of the Polish Carpathians - an annotated checklist. W. Szafer Institute of Botany, Polish Academy of Sciences, Kraków: 239-294. 
Kościelniak R., Kiszka J. 2006. Nowe i rzadkie gatunki porostów w Bieszczadzkim Parku Narodowym i jego otulinie. Część VIII (New and rare lichen species in the Bieszczady National Park and its environs. Part VIII). Roczniki Bieszczadzkie (14): 135-138.

Kukwa M. 2005. Nowe stanowiska rzadkich i interesujących porostów na Pomorzu Gdańskim. Część I (New localities of rare and interesting lichens in Gdańskie Pomerania. Part I). Acta Bot. Cassub. 5: 95-111.

Lipn icki L. 2003. Czerwona lista porostów zagrożonych w Borach Tucholskich (Red List of threatened lichens in the Tucholskie Forest). Monogr. Bot. 91: 79-90.

Rydzak J. 1955. Wpływ małych miast na florę porostów. Część II. Beskidy Zachodnie: Wisła, Ustroń, Muszyna, Iwonicz, Rymanów, Lesko (The influence of small towns on lichen vegetation. Part II. The Western Beskidy: Wisła, Ustroń, Muszyna, Iwonicz, Rymanów, Lesko). Ann. Univ. Mariae CurieSkłodowska, Sec. C 10 (2): 33-66.

Santesson R., Moberg R., Nordin A., Tønsberg T., Vitikainen O.2004. Lichen-forming and lichenicolous fungi of Fennoscandia. Museum of Evolution, Uppsala University, 359 pp.

\section{Usnea florida - zagrożony gatunek bogatych siedlisk w polskich Karpatach Wschodnich}

\section{Streszczenie}

Praca przedstawia wyniki badań nad Usnea florida (L.) Weber ex F.H. Wigg., zagrożonym w Polsce epifitycznym składnikiem bioty Bieszczadzkiego Parku Narodowego. W trakcie badań prowadzonych w latach 2005-2007 stwierdzono trzy nowe stanowiska na terenie Bieszczadzkiego Parku Narodowego (Fig. 1), zlokalizowane w kwadratach ATPOL Gf 6985, Gf 7000, Gg 7024, na wysokości 800-880 m n.p.m. Usnea florida zasiedlała korę Populus termula, Betula sp. i Fagus sylvatica (Fig. 2). Nie potwierdzono historycznych stanowisk tego gatunku znanych z obszaru polskich Karpat Wschodnich (Rydzak 1955; Glanc, Tobolewski 1960). Podczas badań zaobserwowano $\mathrm{w}$ koronach drzew masowo pojawiające się gatunki z rodzaju Usnea (w tym także z owocnikami) i Bryoria (Fig. 3). Daje to podstawę by sądzić, że liczba stanowisk tego gatunku w polskich Karpatach Wschodnich może być większa - zwłaszcza że gatunek ten dość licznie występuje w ukraińskich Karpatach Wschodnich (Bielczyk, informacja ustna).

Usnea florida, ze względu na swoje środowisko życia jest gatunkiem, którego występowanie w Polsce wydaje się nie do końca rozpoznane. Bardzo pomocna może być w tym współpraca z przeszkolonymi służbami leśnymi, która pozwala na monitorowanie koron drzew podczas prowadzenia ich wycinki. Szczególnego znaczenia nabiera to na terenie parków narodowych, w których występowanie tego gatunku jest najbardziej prawdopodobne. Taka współpraca przynosi dobre rezultaty w Bieszczadzkim Parku Narodowym.

Jeśli nawet Usnea florida potraktujemy taksonomicznie szeroko, jako jeden gatunek z U. subfloridana, to i tak owocnikujące formy tego gatunku pozostają niezwykłą rzadkością nie tylko w naszym kraju. Zatem ich obecność w Bieszczadzkim Parku Narodowym podkreśla unikatowy charakter przyrodniczy tego obszaru i jego znaczenie jako ważnej ostoi bioróżnorodności porostów w Karpatach Wschodnich i w Polsce. 


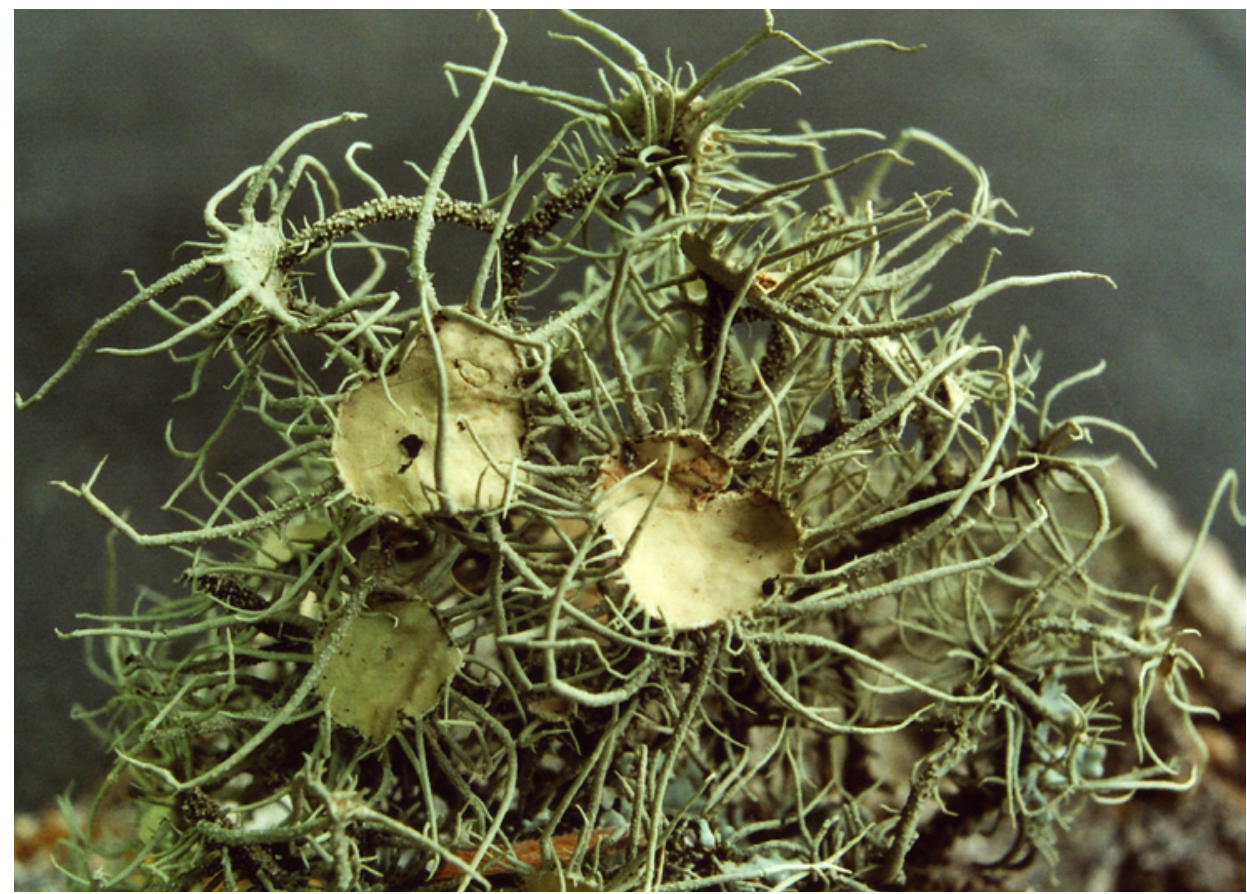

Fig. 2. Habit of Usnea florida from Site I (Kościelniak, KRAP-L).

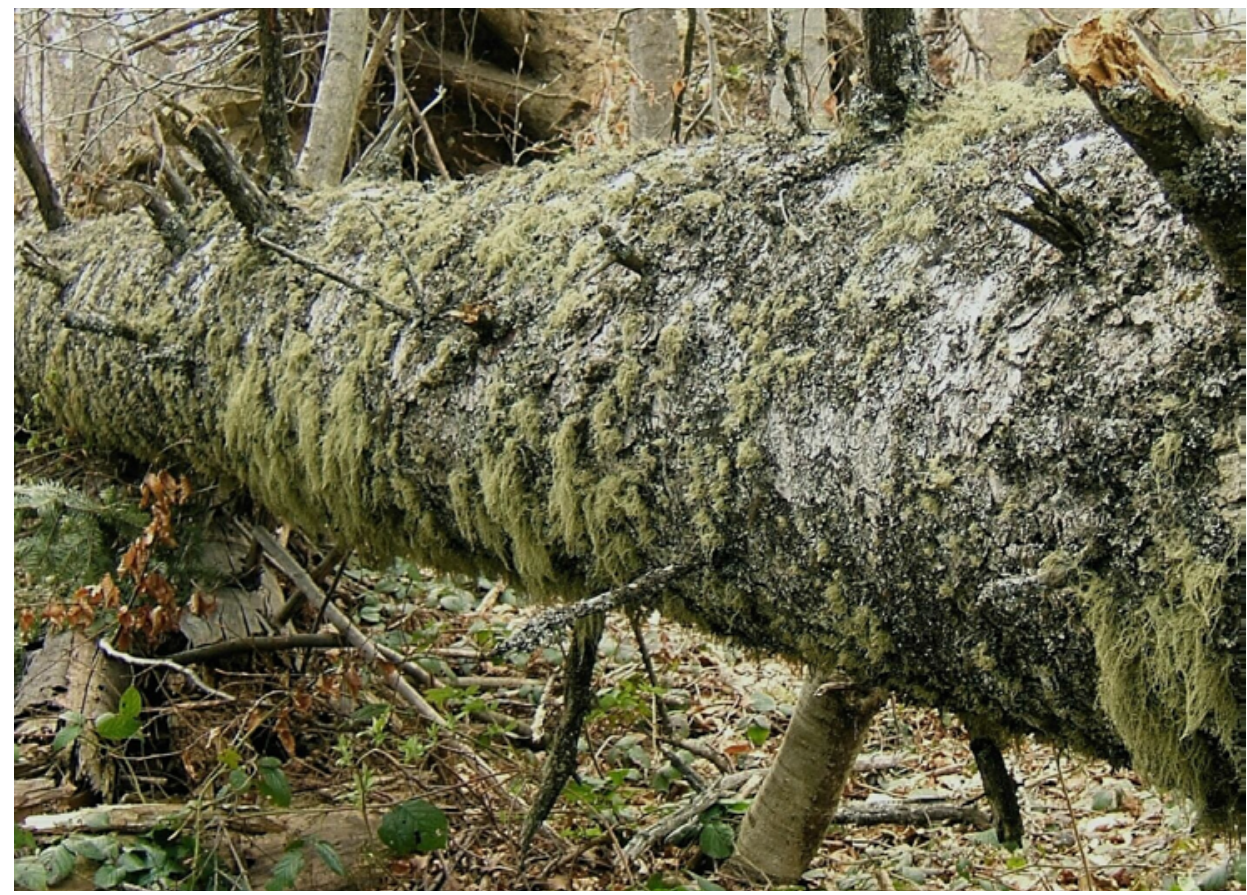

Fig. 3. A blown-down tree-trunk covered with Usnea ssp. 